\title{
RANCANG BANGUN SISTEM BORANG AKREDITASI PROGRAM STUDI TEKNIK ELEKTRO UNIVERSITAS BANGKA BELITUNG
}

\author{
Rudy Kurniawan ${ }^{1}$, Fardhan Arkan ${ }^{2}$ \\ 1,2 Jurusan Teknik Elektro Fakultas Teknik Universitas Bangka Belitung \\ rudy14k@gmail.com
}

\begin{abstract}
In this research, a web-based information systems and database applications for charging and preparation Accreditation Forms of the Study Program (Book III-A) in Electrical Engineering Study Program University of Bangka Belitung. The information system accreditation forms of the study program are manufactured with an integrated system with web applications as interactive media and database as data storage media. Web applications and databases can be used as templete to describe the performance of a study program and can be used to document the internal environment to the needs of the process of accreditation. This application contains a accreditation forms of the study program process, which consists of seven existing standards in Accreditation Forms of the Study Program (Book III-A). Given this information system, the charging process Accreditation Forms of the Study Program has been done manually which is so difficult and time consuming can now be done more easily, practical, and everyone can participate in filling the form so that the work in filling out accreditation forms to be faster, This information system also makes it a team of assessors in the assessment of the document because it can be accessed online.
\end{abstract}

Keywords: Admin, Accreditation Forms, Database, MySQL, PHP, User, Website

INTISARI

Dalam penelitian ini, dibuat sebuah sistem informasi berbasis aplikasi web dan database untuk pengisian dan penyusunan Borang Akreditasi Program Studi (Buku III-A) pada Program Studi Teknik Elektro Universitas Bangka Belitung. Sistem informasi borang akreditasi program studi ini dibuat dengan sistem terintegrasi dengan aplikasi web sebagai media interaktif dan database sebagai media penyimpanan data. Aplikasi web dan database ini dapat dijadikan templete untuk menggambarkan kinerja suatu program studi dan dapat dimanfaatkan untuk mendokumentasikan kondisi internal untuk kebutuhan proses akreditasi program studi. Aplikasi ini berisi form isian (borang) akreditasi program studi yang terdiri dari tujuh standar yang ada di Borang Akreditasi Program Studi (Buku III-A). Dengan adanya Sistem Informasi ini, proses pengisian borang Akreditasi Program Studi yang selama ini dilakukan secara manual yang begitu susah dan memakan waktu sekarang dapat dilakukan dengan lebih mudah, praktis, dan setiap orang dapat berperan serta dalam pengisian borang sehingga pekerjaan dalam pengisian borang menjadi lebih cepat. Sistem Informasi ini juga mempermudah tim asesor dalam melakukan penilaian dokumen karena dapat diakses secara online.

Kata Kunci: Admin, Borang Akreditasi, Database, MySQL, PHP, User, Website

\section{PENDAHULUAN}

Jurusan Teknik Elektro Universitas Bangka Belitung merupakan lembaga yang ada pada institusi pendidikan tinggi Universitas Bangka Belitung di bawah Fakultas Teknik yang memiliki kewajiban untuk menyelenggarakan tridharma perguruan tinggi yaitu pendidikan, penelitian, dan pengabdian pada masyarakat.
Jurusan Teknik Elektro atau Program Studi Teknik Elektro harus dapat menjamin mutu atas penyelenggaraan kegiatan tridharma perguruan tinggi yang dilakukan untuk mencapai peningkatan mutu yang berkelanjutan. Evaluasi mutu program studi dilakukan melalui akreditasi program studi sebagai proses untuk penilaian secara komprehensif atas komitmen program studi terhadap mutu dan kapasitas 
penyelenggaraan program tridharma perguruan tinggi, guna menentukan kelayakan program studi untuk menyelenggarakan program akademiknya. Untuk dapat meningkatkan dedikasi dan menyelenggarakan tridharma perguruan tinggi dengan baik maka Program Studi Teknik Elektro harus terakreditasi.

Untuk mendapatkan status akreditasi program studi, diperlukan informasi mengenai program studi yang didapatkan dari pengisian instrumen penilaian akreditasi dengan terlebih dahulu membuat dokumen evaluasi diri program studi. Sarana yang digunakan untuk mengumpulkan informasi tersebut adalah borang (form isian). Borang akreditasi terdiri dari tujuh standar, yaitu Standar 1 berisi tentang Visi, Misi, Tujuan dan Sasaran, serta Strategi Pencapaian; Standar 2 berisi tentang Tata Pamong, Kepemimpinan, Sistem Pengelolaan, dan Penjaminan Mutu; Standar 3 berisi tentang Mahasiswa dan Lulusan; Standar 4 berisi tentang Sumber Daya Manusia; Standar 5 berisi tentang Kurikulum, Pembelajaran, dan Suasana Akademik; Standar 6 berisi tentang Penelitian, Pelayanan/Pengabdian kepada Masyarakat, dan Kerjasama.

Untuk pengumpulan data dan informasi serta pengisian borang pada program studi Teknik elektro masih dilakukan secara manual. Oleh karena itu, sebuah sistem informasi berbasis komputer sangat diperlukan sebagai sarana untuk menampung dan menyimpan serta menampilkan informasi mengenai program studi. Sistem informasi borang akreditasi program studi Teknik Elektro ini dibuat dengan sistem terintegrasi dengan aplikasi web sebagai media interaktif dan database sebagai media penyimpanan data. Aplikasi web dan database ini dapat dijadikan templete untuk menggambarkan kinerja suatu program studi dan dapat dimanfaatkan untuk mendokumentasikan kondisi internal untuk kebutuhan proses akreditasi program studi.

\section{LANDASAN TEORI}

\section{A. Akreditasi Program Studi}

Berdasarkan BAN-PT, Akreditasi program studi sarjana adalah proses evaluasi dan penilaian secara komprehensif atas komitmen program studi terhadap mutu dan kapasitas penyelenggaraan program tridharma perguruan tinggi, untuk menentukan kelayakan program akademiknya.

Standar akreditasi adalah tolak ukur yang harus dipenuhi oleh program studi sarjana. Standar akreditasi program studi sarjana mencakup standar tentang komitmen program studi sarjana terhadap kapasitas institusional (institusional capacity) dan komitmen terhadap efektivitas program pendidikan (educational effectiveness), yang dikemas dalam tujuh standar akreditasi, yaitu :

1. Standar 1: berisi tentang Visi, Misi, Tujuan dan Sasaran, serta Strategi Pencapaian

2. Standar 2: berisi tentang Tata Pamong, Kepemimpinan, Sistem Pengelolaan, dan Penjaminan Mutu

3. Standar 3: berisi tentang Mahasiswa dan Lulusan

4. Standar 4: berisi tentang Sumber Daya Manusia

5. Standar 5: berisi tentang Kurikulum, Pembelajaran, dan Suasana Akademik

6. Standar 6: berisi tentang Penelitian, Pelayanan/Pengabdian kepada Masyarakat, dan Kerjasama.

Untuk proses penilaian akreditasi program studi harus mengumpulkan borang akreditasi. Borang akreditasi akan dinilai oleh BAN-PT selaku lembaga penjaminan mutu eksternal.

\section{B. Sistem Informasi}

Definisi sistem informasi menurut beberapa pakar adalah sebagai berikut : Sistem informasi adalah suatu kegiatan dari prosedur-prosedur yang diorganisasikan, bilamana dieksekusi akan menyediakan informasi untuk mendukung pengambilan keputusan dan pengendalian di dalam organisasi (Henry C. Lucas).

Sistem informasi adalah suatu kombinasi dari orang-orang, fasilitas, teknologi, media, 
prosedur-prosedur dan pengendalian yang ditujukan untuk mendapatkan jalur komunikasi penting, memproses tipe transaksi rutin tertentu, member sinyal kepada manajemen dan yang lainnya terhadap kejadian-kejadian internal manajemen dan eksternal yang penting dan menyediakan suatu dasar untuk pengambilan keputusan yang cerdik (John F. Nash dan Martin B. Roberts).

Sistem informasi adalah suatu sistem di dalam suatu organisasi yang mempertemukan kebutuhan pengolahan transaksi harian, mendukung operasi, bersifat manajerial dan kegiatan strategi dari suatu organisasi dan menyediakan pihak luar tertentu dengan laporan-laporan yang diperlukan (Robert A. Leitch dan K. Roscoe Davis).

Sistem informasi adalah suatu cara yang sudah tertentu untuk menyediakan informasi yang dibutuhkan oleh organisasi untuk beroperasi dengan cara yang sukses dan untuk organisasi bisnis dengan cara yang menguntungkan (James B. Bower, Robert E. Schlosser dan Maurice S. Newman).

Menurut John Burch dan Gary Grudnitski, komponen sistem informasi terdiri atas :

1. Block Masukan : data yang masuk ke dalam sistem informasi

2. Block Model : kombinasi prosedur, logika dan model matematika yang akan memanipulasi data dengan cara yang sudah tertentu untuk menghasilkan keluaran yang diinginkan.

3. Block Keluaran : informasi yang dihasilkan.

4. Block Teknologi : humanware atau brainware, software dan hardware

5. Block Basis Data : kumpulan data yang saling berhubungan, tersimpan di perangkat keras komputer dan digunakan perangkat lunak untuk memanipulasinya.

6. Block Kendali : pengendalian sistem informasi agar dapat berjalan sesuai dengan yang diinginkan.

\section{Analisis Perancangan Sistem}

Analisis perancangan sistem adalah suatu pendekatan yang sistematis untuk mengidentifikasi masalah, peluang, pencapaian tujuan, menganalisis arus informasi dalam organisasi, serta untuk merancang sistem informasi terkomputerisasi untuk menyelesaikan suatu masalah. Saat informasi berkembang, suatu pendekatan yang sistematis dan terencana untuk memperkenalkan, memodifikasi, dan pemeliharaan sistem informasi menjadi sangat penting. Analisis dan perancangan sistem menampilkan pendekatan semacam itu. Alat bantu perancangan sistem yang digunakan penulis adalah Unified Modelling Language (UML) dan Entity Relationship Diagram (ERD).

\section{PHP dan $M y S Q L$}

PHP adalah script untuk pemrograman web, PHP dapat digunakan bersama-sama dengan kode HTML (embedded). Sehingga hampir mirip dengan javascript, bedanya dengan javascript adalah javascript akan diterjemahkan oleh browser), sedangkan script PHP diterjemahkan di pihak server. Karenanya PHP juga dikenal sebagai server side script. Halaman hasil proses di server, diterima oleh client sebagai HTML biasa, dan kode-kode PHP tidak akan bisa terbaca oleh client. Hal ini juga yang membedakan PHP dengan javascript. Script PHP ini mulai bekerja saat adanya request PHP file tersebut dari Web-browser. Web-server kemudian akan memanggil file tersebut, dan akan membaca semua request dari atas sampai bawah. Mengeksekusi beberapa script command, dan mengirimkan hasilnya dalam sebuah halaman HTML melalui browser.

MYSQL adalah suatu sistem manajemen database. Database merupakan kumpulan data terorganisasi yang digunakan semestinya, menjadi informasi. Untuk mengelola suatu database agar menjadi informasi yang mudah diakses maka membutuhkan suatu sistem pengolahan yang disebut Sistem Manajemen Basis Data/Database Management System (DBMS).

\section{E. XAMPP}

XAMPP adalah perangkat lunak yang fungsinya adalah sebagai server yang berdiri 
sendiri (localhost), yang terdiri atas program Apache HTTP Server, MySQL database, dan penerjemah bahasa yang ditulis dengan bahasa pemrograman PHP dan Perl.Na ma XAMPP merupakan singkatan dari $X$ (Empat sistem operasi apapun), Apache, MySQL, PHP dan Perl. Program ini tersedia dalam General Public License (GNU) dan bebas, XAMPP merupakan webserver yang mudah digunakan yang dapat melayani tampilan halaman web yang dinamis. Dengan menginstal XAMPP, maka tidak perlu lagi melakukan instalasi dan mengkonfigurasikan Apache, $P H P$ dan $M y S Q L$ secara manual. XAMPP akan melakukan hal tersebut secara otomatis.

\section{METODE PENELITIAN}

\section{A. Tahapan Penelitian}

Tahapan yang dilakukan di dalam penelitian ini yaitu studi literatur, perancangan sistem, pencarian dan pemilihan bahan, implementasi sistem, pengujian dan pengambilan data sistem, analisa sistem, dan penulisan laporan penelitian sesuai dengan diagram alir pada Gambar 1 .

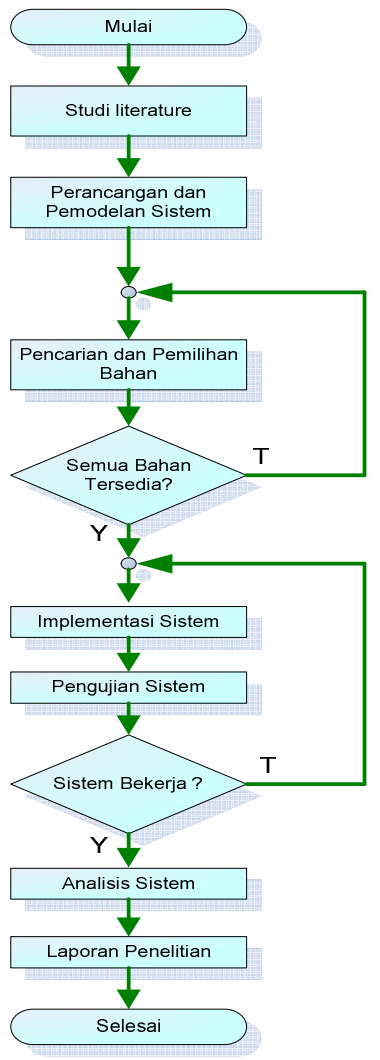

Gambar 1. Tahapan yang akan dilakukan

\section{B. Perancangan Sistem}

1. Arsitektur Sistem

Arsitektur dari sistem yang dibuat pada penelitian ini secara keseluruhan dapat dilihat pada Gambar 2.

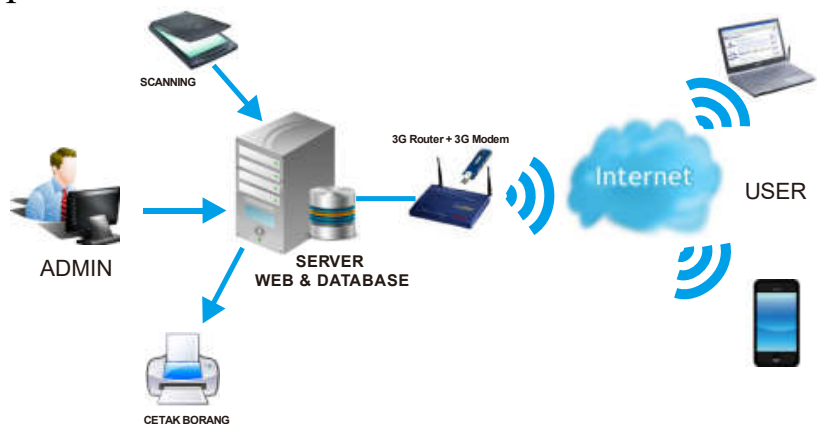

Gambar 2. Arsitektur sistem

2. Perancangan Use Case Diagram

Use Case Diagram dari sistem informasi borang akreditasi yang ditunjukkan pada Gambar 3.

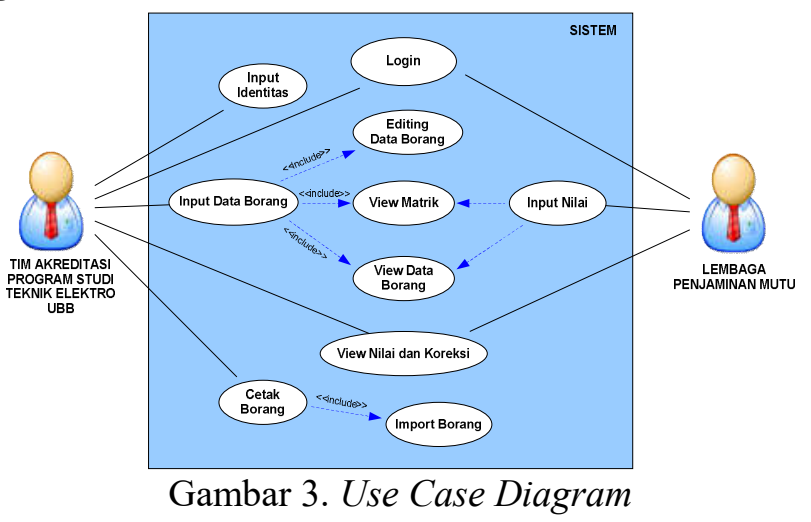

3. Perancangan Context Diagram

Context Diagram dari sistem informasi borang akreditasi yang ditunjukkan pada Gambar 4.

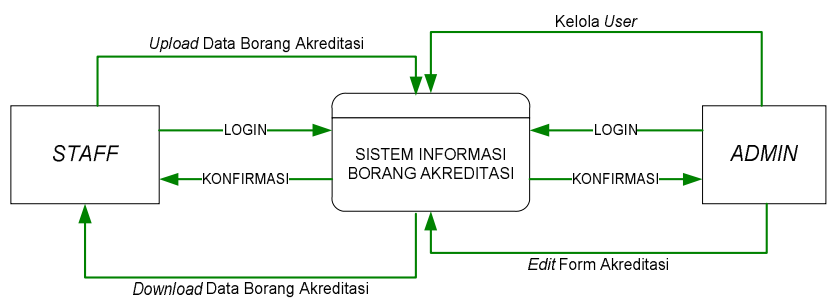

Gambar 4. Context Diagram

4. Perancangan Data Flow Diagram

Data Flow Diagram merupakan tahap perancangan aplikasi yang menggambarkan aliran data dan penyimpanan data. Alur data dan proses dasar apa saja yang ada pada aplikasi ini. 
Berikut adalah DFD dari sistem informasi borang akreditasi.

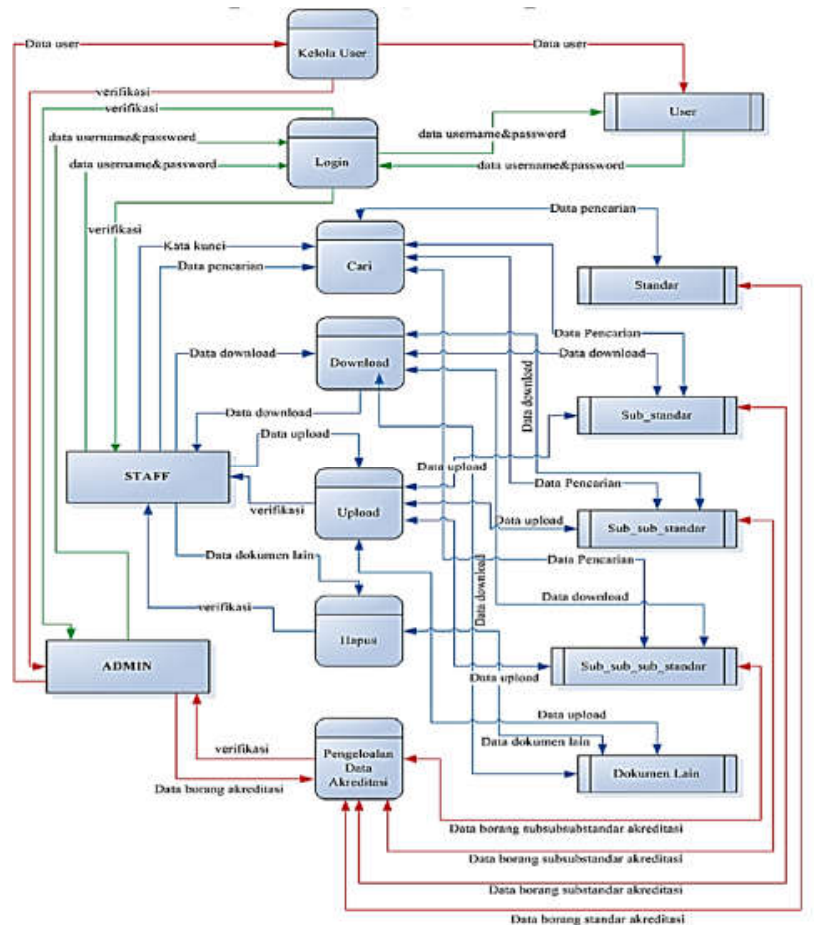

Gambar 5. DFD Sistem Informasi Borang

\section{Perancangan Entity Relationship Diagram}

ERD yang terdapat dalam sistem borang akreditasi yang ditunjukkan pada Gambar 6 .

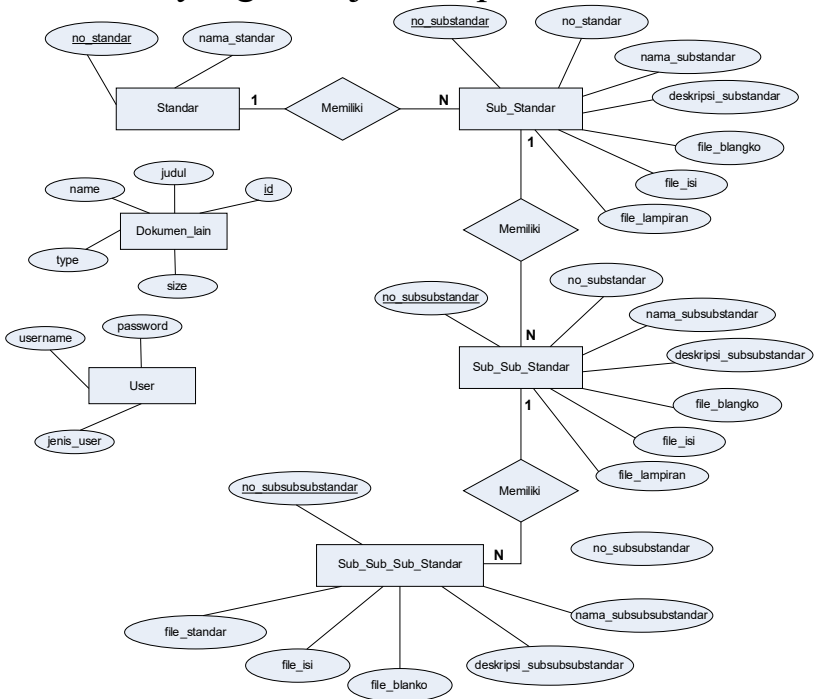

Gambar 6. ERD

\section{Perancangan Database}

Database sebagai penyedia data dan untuk memproses query dari parameter yang dikirim/diminta oleh client. Pada penelitian ini digunakan Database server MySQL sebagai penyimpan data yang akan ditampilkan melalui web dengan nama database "borang_akreditasi" dengan rincian lengkap seperti pada Tabel 1 .

Tabel 1. Rincian database "borang akreditasi"

\begin{tabular}{|c|c|c|}
\hline No & Table & Field \\
\hline 1. & pengisian borang & 5 \\
\hline 2. & $p s$ & 17 \\
\hline 3. & dikti & 2 \\
\hline 4. & standar1_1_1 & 2 \\
\hline 5. & standar1_1_2 & 2 \\
\hline 6. & standar1_1_3 & 2 \\
\hline 7. & standar1_1_4 & 2 \\
\hline 8. & standar1_1_5 & 3 \\
\hline 9. & standar1_2- & 2 \\
\hline 10. & standar2_1 & 2 \\
\hline 11. & standar2_2 & 2 \\
\hline 12. & standar2_3 & 3 \\
\hline 13. & standar $2 \_4$ & 3 \\
\hline 14. & standar2_5_alumni & 3 \\
\hline 15. & standar2_5_dosen & 3 \\
\hline 16. & standar2_5_lulusan & 3 \\
\hline 17. & standar2_5_mahasiswa & 3 \\
\hline 18. & standar2_6_a & 2 \\
\hline 19. & standar2_6_b & 2 \\
\hline 20. & standar2_6_c & 2 \\
\hline 21. & standar2_6_d & 2 \\
\hline 22. & standar2_6_e & 2 \\
\hline 23. & standar3_1_1_ts & 16 \\
\hline 24. & standar3_1_1_ts 1 & 16 \\
\hline 25. & standar3_1_1_ts2 & 16 \\
\hline 26. & standar3_1_1_ts3 & 16 \\
\hline 27. & standar3_1_1_ts4 & 16 \\
\hline 28. & standar3_1_2 & 9 \\
\hline 29. & standar3_1_3 & 5 \\
\hline 30. & standar3_1_4 & 9 \\
\hline 31. & standar3_2_a & 4 \\
\hline 32. & standar3_2_b & 4 \\
\hline 33. & standar3_2_c & 4 \\
\hline 34. & standar3_2_d & 4 \\
\hline 35. & standar3_2_e & 4 \\
\hline 36. & standar3_3_1a & 4 \\
\hline 37. & standar3_3_1b & 3 \\
\hline 38. & standar3_3_1_tbl_hasil_a & 5 \\
\hline 39. & standar3_3_1_tbl_hasil_b & 5 \\
\hline 40. & standar3_3_1_tbl_hasil_c & 5 \\
\hline 41. & standar3_3_1_tbl_hasil_d & 5 \\
\hline 42. & standar3_3_1_tbl_hasil_e & 5 \\
\hline 43. & standar3_3_1_tbl_hasilf $f$ & 5 \\
\hline 44. & standar3_3_1_tbl_hasil_g & 5 \\
\hline 45. & standar3_3_2 & 3 \\
\hline 46. & standar3_3_3 & 3 \\
\hline 47. & standar3_4_akademik & 3 \\
\hline 48. & standar3_4_nonakademik & 3 \\
\hline 49. & standar4_1 & 2 \\
\hline 50 & standar4_2 & 2 \\
\hline 51. & standar4_3_1 & 3 \\
\hline 52. & standar4_3_2 & 3 \\
\hline 53. & standar4_3_3 & 3 \\
\hline 54. & standar4_3_3_jmlh & 3 \\
\hline 55. & standar4_3_3_rata2 & 3 \\
\hline 56. & standar4_3_4 & 3 \\
\hline 57. & standar4_3_5 & 3 \\
\hline 58. & standar4_4_1 & 3 \\
\hline 59. & standar4_4_2 & 3 \\
\hline 60 & standar4_4_2_jmlh & 3 \\
\hline 61. & standar4_5_1 & 3 \\
\hline 62. & standar4_5_2 & 3 \\
\hline 63. & standar4_5_3 & 3 \\
\hline 64. & standar4_5_4 & 3 \\
\hline 65 & standar4_5_5 & 3 \\
\hline 66. & standar4_6_1_admin & 3 \\
\hline
\end{tabular}




\begin{tabular}{|c|c|c|}
\hline No & Table & Field \\
\hline 67. & standar4_6_1_laboran & 3 \\
\hline 68. & standar4_6_1_lainnya & 3 \\
\hline 69. & standar4_6_1_pustakawan & 3 \\
\hline 70. & standar4_6_1_total & 3 \\
\hline 71. & standar4_6_2 & 3 \\
\hline 72. & standar5_1_1_1 & 3 \\
\hline 73. & standar5_1_1_2 & 3 \\
\hline 74. & standar5_1_1_3 & 3 \\
\hline 75. & standar5_1_2_1_mk_pilihan & 3 \\
\hline 76. & standar5_1_2_1_mk_wajib & 3 \\
\hline 77. & standar5_1_2_1 total & 3 \\
\hline 78. & standar5_1_2_2_smt1 & 3 \\
\hline 79. & standar5_1_2_2_smt2 & 3 \\
\hline 80. & standar5_1_2_2_smt3 & 3 \\
\hline 81. & standar5_1_2_2_smt4 & 3 \\
\hline 82. & standar5_1_2_2_smt5 & 3 \\
\hline 83. & standar5_1_2_2_smt6 & 3 \\
\hline 84. & standar5_1_2_2_smt7 & 3 \\
\hline 85. & standar5_1_2_2_smt8 & 3 \\
\hline 86. & standar5_1_2_2_totalsks & 3 \\
\hline 87. & standar5_1_3 & 3 \\
\hline 88. & standar5_1_3_total_sks & 3 \\
\hline 89. & standar5_1_4 & 3 \\
\hline 90. & standar5_2- & 3 \\
\hline 91. & standar5_2_hasil & 3 \\
\hline 92. & standar5_3_1 & 3 \\
\hline 93. & standar5_4_1 & 3 \\
\hline 94. & standar5_4_1_rata2 & 3 \\
\hline 95. & standar5_4_1_total & 3 \\
\hline 96. & standar5_4_2_kesulitan & 3 \\
\hline 97. & standar5_4_2_manfaat & 3 \\
\hline 98. & standar5_4_2_masalah & 3 \\
\hline 99. & standar5_4_2_pelaksanaan & 3 \\
\hline 100. & standar5_4_2_tujuan & 3 \\
\hline 101. & standar5_5_1 & 3 \\
\hline 102. & standar5_5_1_penjelasan & 3 \\
\hline 103. & standar5_6_evaluasi & 3 \\
\hline 104. & standar5_6_materi & 3 \\
\hline 105. & standar5_6_metode & 3 \\
\hline 106. & standar5_6_teknologi & 3 \\
\hline 107. & standar5_7_1 & 3 \\
\hline 108. & standar5_7_2 & 3 \\
\hline 109. & standar $5-73$ & 3 \\
\hline 110. & standar5_7_4 & 3 \\
\hline 111. & standar 5 - 75 & 3 \\
\hline 112. & standar6_1 & 3 \\
\hline 113. & standar6_2_1_diknas & 3 \\
\hline 114. & standar6_2_1_lainnya & 3 \\
\hline 115. & standar6_2_1_mypt & 3 \\
\hline 116. & standar6_2_1_pendidikan & 3 \\
\hline 117. & standar6_2_1_penelitian & 3 \\
\hline 118. & standar6_2_1_pengabdian & 3 \\
\hline 119. & standar6_2_1_pengguna_lainnya & 3 \\
\hline 120. & standar6_2_1_prasarana & 3 \\
\hline 121. & standar6_2_1_sarana & 3 \\
\hline 122. & standar6_2_1_sdm & 3 \\
\hline 123. & standar6_2_1_total & 3 \\
\hline 124. & standar6_2_1_yayasan & 3 \\
\hline 125. & standar6_2_2 & 3 \\
\hline 126. & standar6_2_3 & 3 \\
\hline 127. & standar6_3_1_lebih4 & 3 \\
\hline 128. & standar6_3_1_total_luas & 3 \\
\hline 129. & standar6_3_1_utk1_nonstruktural & 3 \\
\hline 130. & standar6_3_1_utk2 & 3 \\
\hline 131. & standar6_3_1_utk3dan4 & 3 \\
\hline 132. & standar6_3_2 & 3 \\
\hline 133. & standar6_3_3 & 3 \\
\hline 134. & standar6_4_1_buku_teks & 3 \\
\hline 135. & standar6_4_1_disertasi & 3 \\
\hline 136. & standar6_4_1_jurnal_akreditasi_dikti & 3 \\
\hline 137. & standar6_4_1_jurnal_inter & 3 \\
\hline
\end{tabular}

\begin{tabular}{clc}
\hline No & \multicolumn{1}{c}{ Table } & Field \\
\hline 138. & standar6_4_1_jurnal_nas_akreditasi & 3 \\
139. & standar6_4_1_prosiding & 3 \\
140. & standar6_4_1_skripsi_tesis & 3 \\
141. & standar6_4_1_total & 3 \\
142. & user & 5 \\
\hline
\end{tabular}

\section{HASIL DAN PEMBAHASAN}

\section{A. Tampilan Database}

Hasil tampilan halaman database pada phpMyAdmin yang berhasil dibuat dan dijalankan pada browser diperlihatkan pada Gambar 7.

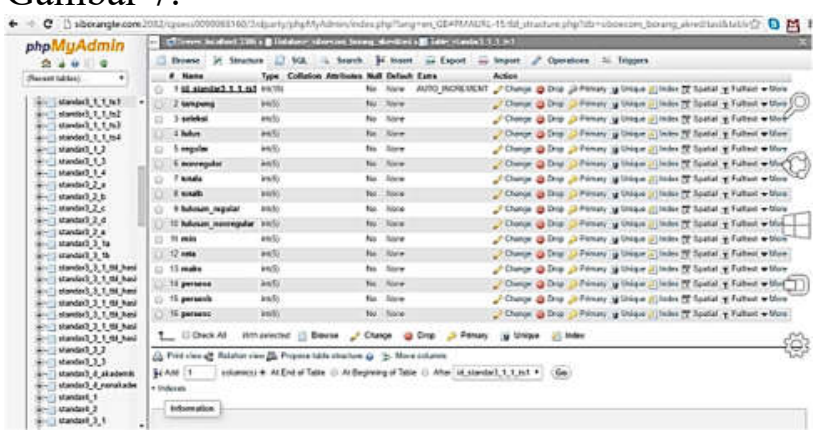

Gambar 7. Tampilan Database pada phpMyAdmin

\section{B. Tampilan Website Keseluruhan}

Hasil tampilan halaman utama website yang berhasil dijalankan pada browser diperlihatkan pada Gambar 8.

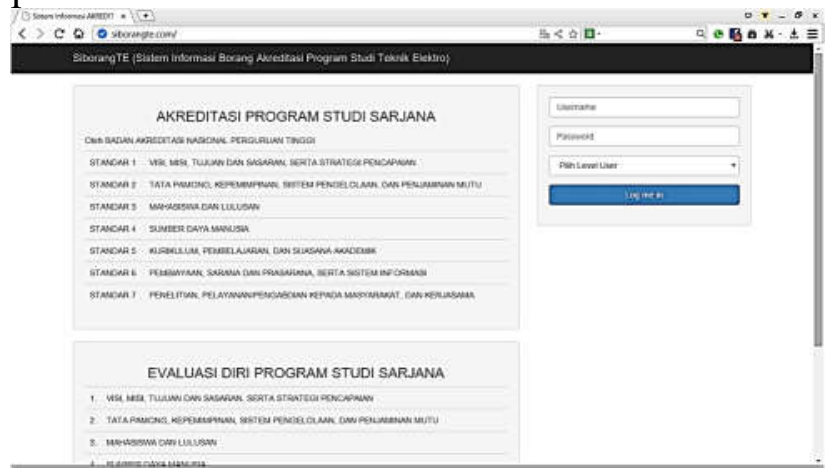

Gambar 8. Tampilan Halaman Utama

\section{Tampilan Login}

Hasil tampilan login website yang berhasil dijalankan pada browser diperlihatkan pada Gambar 9. User dapat memilih level user baik sebagai Administrator, Dosen, atau Asesor. 


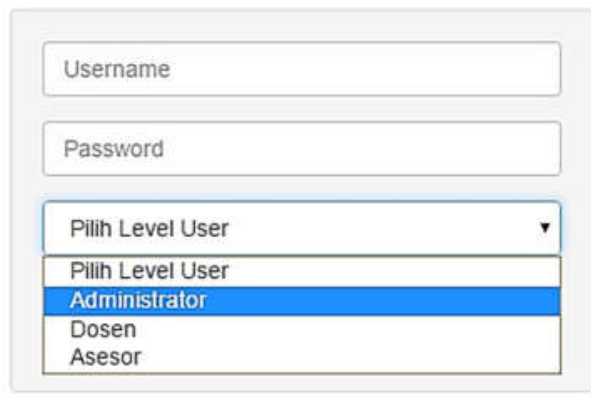

Gambar 9. Tampilan pilihan Login

\section{Tampilan Halaman Admin}

Hasil tampilan halaman admin yang berhasil dijalankan pada browser diperlihatkan pada Gambar 10.

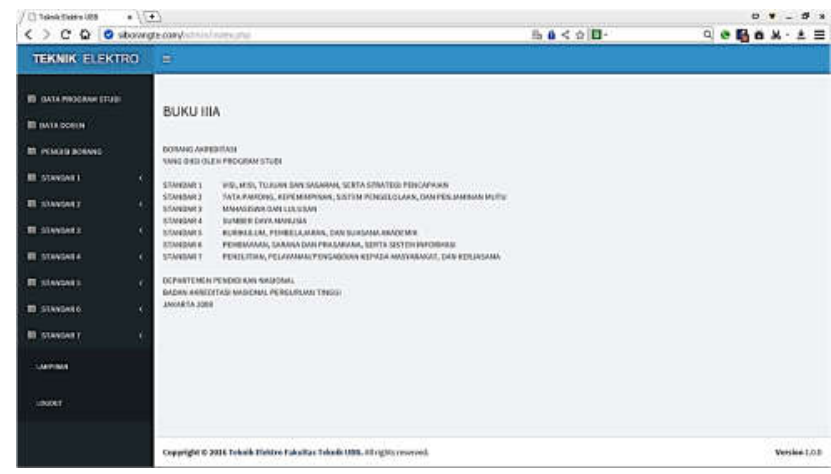

Gambar 10. Tampilan Halaman Admin

\section{E. Tampilan Halaman Isian Form (Borang)}

Hasil tampilan halaman isian form (borang) pada halaman Admin yang berhasil dijalankan pada browser diperlihatkan pada Gambar 11.

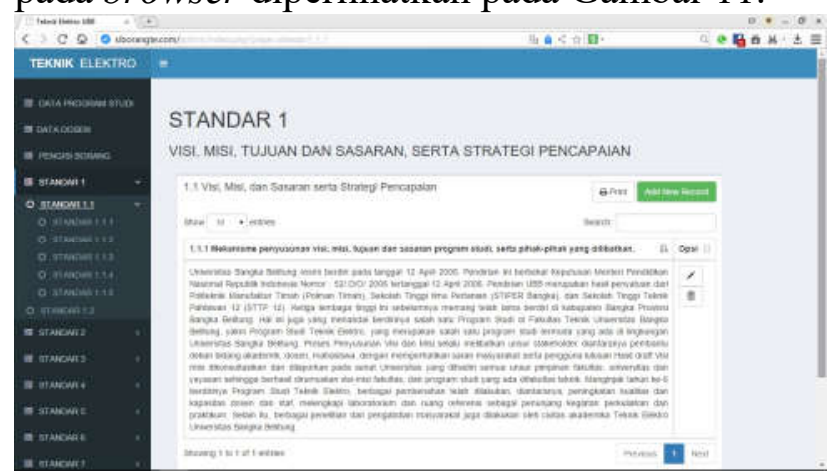

Gambar 11. Tampilan Halaman Isian Form

\section{F. Tampilan Halaman Edit atau \\ Pembaharuan Data Borang}

Hasil tampilan halaman edit data atau perbaharuan data borang pada halaman Admin yang berhasil dijalankan pada browser diperlihatkan pada Gambar 12. Admin dapat mengubah atau memperbarui data pada tampilan halaman ini.

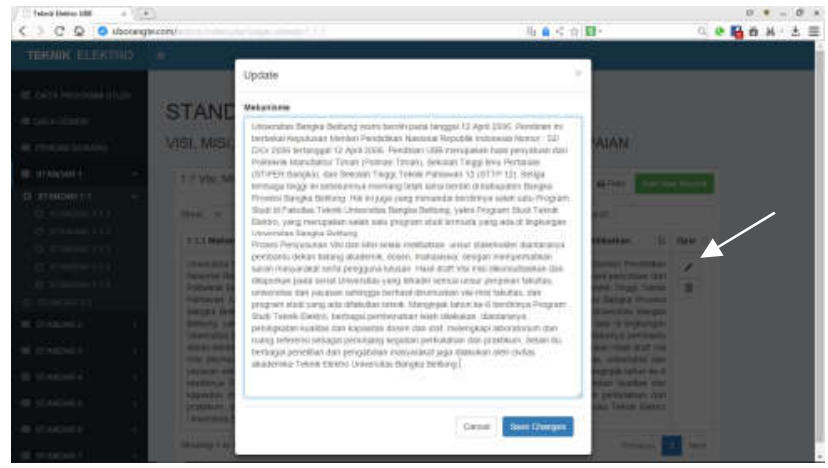

Gambar 12. Tampilan Halaman Edit Data

\section{G. Tampilan Halaman Print-out}

Hasil tampilan halaman print-out pada halaman website yang diprint dan berhasil dijalankan pada browser diperlihatkan pada Gambar 13.

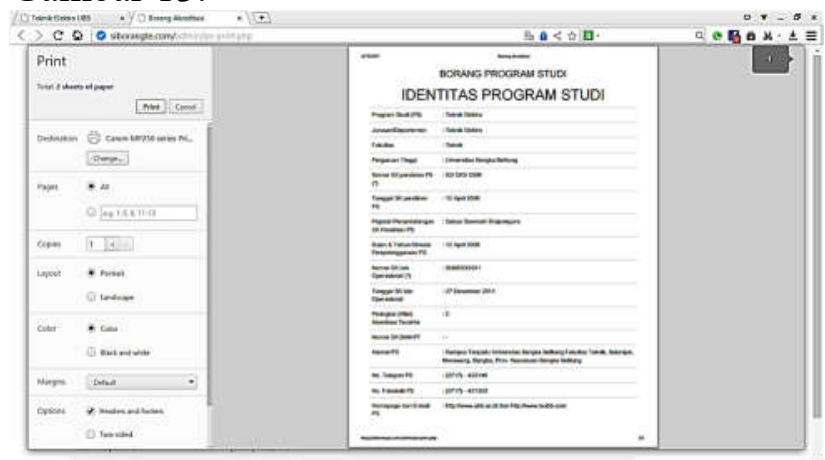

Gambar 13. Tampilan Halaman Print-out Data Borang

\section{KESIMPULAN}

Dari hasil penelitian yang telah dilakukan maka didapatkan beberapa kesimpulan sebagai berikut:

1. Sistem Informasi Borang Akreditasi Program Studi Teknik Elektro telah dibuat dan mempermudah proses pengelolaan dan penyimpanan data-data akreditasi ke dalam database dan ditampilkan dalam website.

2. Sistem Informasi Borang Akreditasi Program Studi Teknik Elektro memiliki tiga pilihan level user yaitu level sebagai administrator yang dapat melakukan edit, upload dan download/print-out data borang akreditasi, level sebagai dosen yang dapat 
melakukan update data borang, dan level sebagai asesor yang dapat melakukan download/print-out data borang Akreditasi.

3. Perancangan Sistem Informasi Borang Akreditasi Program Studi Teknik Elektro sesuai dengan analisis sistem usulan dan dirancang dalam aplikasi berbasis web untuk dokumentasi borang akreditasi, data disimpan dalam database dan dikelola untuk peningkatan kinerja program studi.

\section{REFERENSI}

[1] Nugroho, Bambang, 2011, Pembuatan Sistem Informasi Borang Akreditasi Jurusan DIII Teknik Informatika Universitas Sebelas Maret Surakarta. Universitas Sebelas Maret Surakarta, Surakarta

[2] Fauzi, A., Komarudin, O., 2012, Perancangan Perangkat Lunak Borang Akreditasi Program Studi. Jurnal Fakultas Ilmu Komputer Universitas Singaperbangsa Karawang, Karawang

[3] Putro, E., 2014, Aplikasi Sistem Penyusunan Borang Akreditasi Program Studi (Buku III-A), Jurnal Teknik dan Ilmu Komputer Vol. 03 No. 09 Maret 2014. Universitas Kristen Krida Wacana, Jakarta

[4] Kadir, A., 2009, Pengenalan Sistem Informasi, Andi Publisher, Yogyakarta

[5] Indrajani, 2011, Pengantar dan Sistem Basis Data, Elek Media Komputindo, Jakarta

[6] Jogiyanto, H. M., (2001), Analisis dan Desain Sistem Informasi. Andi Yogyakarta, Yogyakarta

[7] Fatansyah, 2002, Basis Data, Informatika, Bandung.

[8] Boronczyk, T., 2009, Beginning PHP6, MySQL, Apache. Wiley Publishing Inc, Indiana Polis

[9] 2008, Buku III-A Borang Akreditasi Program Studi. BAN-PT

[10] _ 2008, Panduan Pengisian Borang Akreditasi Program Studi. BANPT
[11] ,2009, Buku 1 Naskah Akademik Akreditasi Program Studi Sarjana. (www.banpt.diknas.go.id) 